\title{
Sustained activation of Erk1/2 MAPK and cell growth suppression by the insert-negative, but not the insert-positive isoform of the human calcitonin receptor
}

\author{
L-J Raggatt, A Evdokiou and D M Findlay \\ Department of Orthopaedics and Trauma, University of Adelaide, The Royal Adelaide Hospital, Adelaide 5000, South Australia, Australia \\ (Requests for offprints should be addressed to D M Findlay, Department of Orthopaedics and Trauma, Level 4, Bice Building, Royal Adelaide Hospital, \\ North Terrace, Adelaide 5000, South Australia, Australia; Email: david.findlay@adelaide.edu.au)
}

\begin{abstract}
Recently we reported that calcitonin (CT) induces growth arrest at the G2 stage of the cell cycle in HEK-293 cell lines expressing the most abundant, insert-negative, isoform of the human CT receptor (insert - ve hCTR). The present study investigates the involvement of the MAPK signalling pathway in the anti-proliferative actions of CT and compares the activity of an isoform of the hCTR that contains a 16 amino acid insert in the first putative intracellular loop (insert +ve hCTR). Comparison of HEK-293 cells stably transfected with the insert - ve or the insert +ve hCTR, showed that accumulation of cAMP and intracellular free calcium in response to CT were specific for the insert - ve receptor isoform. However, a novel acidification of the extracellular medium was mediated by both isoforms. Treatment with CT of cells expressing the insert - ve hCTR, caused a decrease in cell
\end{abstract}

growth associated with an induction of $\mathrm{p} 21^{\mathrm{WAF} 1 / \mathrm{CIP} 1}$. Analysis by fluorescence-activated cell scanning showed that growth inhibition was associated with an accumulation of cells in G2. CT treatment of cells expressing the insert - ve, but not insert +ve hCTR, induced the phosphorylation of Erk1/2 MAPK, which persisted for at least $72 \mathrm{~h}$. Treatment of cells expressing the insert - ve hCTR with the MAPK kinase (MEK) inhibitor, PD98059, inhibited the phosphorylation of Erk1/2 and abrogated the growth inhibitory effects of salmon CT, the accumulation of cells in G2, and the associated induction of $\mathrm{p} 21^{\mathrm{WAF} 1 / \mathrm{CIP} 1}$. These data suggest that activation of Erk1/2 are downstream effectors of the insert - ve hCTR in modulating cell cycle progression.

Journal of Endocrinology (2000) 167, 93-105

\section{Introduction}

Calcitonin (CT) is a 32 amino acid peptide hormone of thyroidal origin, with receptor-mediated effects in bone (Chambers \& Magnus 1982), kidney (Marx et al. 1972), placenta (Nicholson et al. 1988) and the central nervous system (Fischer et al. 1981). However, CT and its receptor (CTR) have been identified in a number of other cell types and tissue sites, both developmentally (Jagger et al. 1999) and in maturity (Kuestner et al. 1994). Expression of the CTR has also been shown in human cancer cell lines (Findlay et al. 1980a, b, 1981, Gorn et al. 1992, Shah et al. 1994) and primary cancers originating in a variety of tissues (Gillespie et al. 1997).

The CTR belongs to a subclass of the seventransmembrane domain (7 TMD) G-protein coupled receptor (GPCR) family, which includes receptors for parathyroid hormone (PTH), PTH-related peptide, glucagon, vasoactive intestinal peptide, pituitary adenylate cyclase activating peptide, and other peptide agonists (Spengel \& Eva 1994). Cloning of the CTR has indicated the existence of multiple isoforms, which result from alternative splicing of the primary mRNA transcript (Gorn et al. 1992). In the case of the human CTR (hCTR), at least five splice variants have been described. The two most common isoforms comprise an insert-negative form (insert - ve) and a form that contains 16 additional amino acids in the first putative intracellular loop, the insertpositive (insert $+\mathrm{ve}$ ) isoform (Kuestner et al. 1994). When expressed in a number of cell types the insert + ve receptor isoform displays similar affinity for CT as the insert - ve variant (Nussenzveig et al. 1994, Albrandt et al. 1995, Gorn et al. 1995, Moore et al. 1995) but has markedly altered G-protein coupling efficiency (Gorn et al. 1995, Moore et al. 1995). The presence of the 16 amino acid insert leads to a complete loss of intracellular calcium mobilisation in response to CT (Albrandt et al. 1995, Moore et al. 1995). The ability of the insert + ve isoform to signal via Gs is affected in a cell-type specific manner, generally with decreasing efficiency, leading to a greatly reduced potency of CT for stimulation of cAMP production (Nussenzveig et al. 1994, Albrandt et al. 1995, Moore et al. 1995). 
The CTR can also activate additional intracellular signalling pathways, including activation of phospholipase $\mathrm{D}$ (Naro et al. 1998) and tyrosine kinases (Zhang et al. 1999). In particular, activation of the rabbit CTR transfected into HEK-293 cells caused a rapid, but transient activation of the MAPK pathway, by mechanisms involving $\mathrm{G} i$ and pertussis toxin-insensitive protein kinase $\mathrm{C}$ (PKC) activation (Chen et al. 1998). Activation of the MAPK signalling pathway has been shown to be centrally involved in cell growth regulation (Gutkind 1998), and paradoxically can contribute to either mitogenesis (Mansour et al. 1994) or growth suppression (Pumiglia \& Decker 1997). The involvement of the Erk1/2 MAPK pathway in CTR-mediated growth suppression has not been established. We recently reported that CT profoundly inhibited the growth of HEK-293 cells transfected with the insert - ve form of hCTR (Evdokiou et al. 1999). CT treatment of these cells resulted in an accumulation of cells in the G2 phase of the cell cycle, associated with a prolonged increase in expression of the cyclindependent kinase inhibitor $\mathrm{p} 21^{\mathrm{WAF} 1 / \mathrm{CIP} 1}$. These results were consistent with previous observations showing growth modulatory actions of CT in a variety of cell types (Ng et al. 1983, Shah et al. 1994, Ritchie et al. 1997). Moreover, there is a growing body of evidence for an important role for GPCR in influencing cell growth and differentiation (Gutkind 1998).

In order to develop an understanding of the physiological role of the hCTR isoforms, the present experiments were designed to compare the effects of CT treatment on the growth of HEK-293 cells stably transfected with either the insert - ve or insert +ve hCTR. We report that CTR-mediated growth suppression was specific for the insert - ve isoform of the receptor. In addition, growth suppression was associated with a delayed and sustained activation of the Erk1/2 MAPK pathway that was not observed in cells transfected with the insert +ve hCTR. Activation of Erk1/2 MAPK was coincidental with the effects of CT on $\mathrm{p} 21^{\mathrm{WAF} 1 / \mathrm{CIP} 1}$ induction and on its suppression of cell growth. This CT-induced induction of $\mathrm{p} 21^{\mathrm{WAF} 1 / \mathrm{CIP} 1}$ and cell growth suppression were inhibited with the suppression of Erk1/2 phosphorylation.

\section{Materials and Methods}

\section{Cell culture}

Human embryonic kidney (HEK-293) cells were maintained in Dulbecco's Modified Eagle's medium (DMEM) (ICN, Aurora, OH, USA) supplemented with 10\% heat-inactivated fetal bovine serum (FCS) (TRACE Biosciences, Victoria, Australia), $2 \mathrm{mM}$ glutamine, $100 \mathrm{U} / \mathrm{ml}$ penicillin, and $0.1 \mathrm{mg} / \mathrm{ml}$ streptomycin, as previously reported. Stably transfected HEK-293 cells were maintained in $200 \mu \mathrm{g} / \mathrm{ml} \mathrm{G} 418$ (Gibco BRL, Glen Waverley, Victoria, Australia), which was removed prior to commencement of experiments. Cells were grown at $37^{\circ} \mathrm{C}$ in a humidified atmosphere with $5 \% \mathrm{CO}_{2}$.

\section{Stable transfection of HEK-293 cells}

The establishment of HEK-293 cell lines stably expressing the insert - ve form of the hCTR has been reported previously (Evdokiou et al. 1999). To enable comparison of the growth effects of this insert - ve hCTR with the insert +ve isoform of the hCTR in the same cell type, HEK-293 cells stably transfected with the insert +ve isoform of hCTR were established. The hCTR insert + ve cDNA (a gift from Zymogenetics Inc., Seattle, WA, USA) was cloned into the mammalian expression vector $p R c-$ CMV (Invitrogen, Carlsbad, CA, USA). Using a modified calcium phosphate transfection method (Wigler et al. 1977), cells at approximately $50 \%$ confluence were transfected with $10 \mu \mathrm{g}$ plasmid DNA, together with $20 \mu \mathrm{g}$ herring sperm DNA (Sigma Chemical Co., St Louis, MO, USA), in $25 \mathrm{~cm}^{2}$ culture flasks. Twenty-four hours after transfection, G418 selection was commenced with the addition of $400 \mu \mathrm{g} / \mathrm{ml} \mathrm{G} 418$ and maintained for 2 weeks. Neomycin-resistant colonies were picked manually, propagated in the continual presence of G418 $(200 \mu \mathrm{g} / \mathrm{ml})$, and screened for binding of ${ }^{125}$ I-labelled salmon CT $(\mathrm{sCT})$. A number of clones were obtained with different levels of receptor expression. The cell line designated Hi12, which expressed $\sim 2.29 \times 10^{6}$ receptors/cell, and bound ${ }^{125} \mathrm{I}-\mathrm{sCT}$ with a $K_{\mathrm{d}} \sim 3.3 \mathrm{nM}$, was primarily used for this study. A second clone expressing the insert +ve hCTR, termed Hi5 $\left(\sim 3.06 \times 10^{6}\right.$ receptors/cell, $\left.K_{\mathrm{d}} \sim 3.24 \mathrm{nM}\right)$, is also discussed.

Parental HEK-293 cells were transfected with the mammalian expression vector Zem228CC alone, using the above protocol. In this case a pool of G418-resistant clones was used.

\section{Receptor binding assay}

Cells were grown in 24-well plates (Corning, Costar Corp., Cambridge, MA, USA) until confluent, growth media was removed and binding buffer added (DMEM containing $0 \cdot 1 \% \mathrm{BSA}) .{ }^{125} \mathrm{I}-\mathrm{sCT}(\sim 80 \mathrm{pM})$ was added to all wells in the absence (total binding) and presence of increasing concentrations of unlabelled sCT ligand (Penninsular Laboratories Inc., Belmont, CA, USA). Nonspecific binding was defined as the binding in the presence of $10^{-7} \mathrm{M}$ unlabelled sCT. Cells were incubated for $1 \mathrm{~h}$ at $37^{\circ} \mathrm{C}$ in $5 \% \mathrm{CO}_{2}$, then washed twice with PBS to remove unbound radioactivity and solubilised in $0.5 \mathrm{M}$ $\mathrm{NaOH}$. Samples were counted in a gamma counter to determine cell-bound radioactivity. The results are representative of at least two independent experiments performed in triplicate. 
cAMP assay

To measure the ability of the two hCTR isoforms to activate adenylate cyclase, intracellular cAMP was measured using an enzyme immunoassay kit (Amersham Pharmacia Biotech, Amersham, Bucks, UK). Cells were plated in 96-well plates $\left(2 \times 10^{4} /\right.$ well $)$ for 3 days prior to performing the assay. Cells were exposed to the indicated concentrations of $\mathrm{sCT}$ for $15 \mathrm{~min}$ at $37^{\circ} \mathrm{C}$ in $5 \% \mathrm{CO}_{2}$. Media were then removed and cells were lysed, using the lysis buffer provided, to release intracellular cAMP. The assay was then performed according to the manufacturer's instructions.

\section{Intracellular calcium assay}

The quantification of CT-induced changes in intracellular calcium was performed as described previously (Halliday et al. 1993). Cells were grown in a $75 \mathrm{~cm}^{2}$ culture flask until confluent, trypsinised and resuspended in serum-depleted DMEM containing 1.0 $\mu \mathrm{M}$ Fura-2AM (Calbiochem, La Jolla, CA, USA). Cells were incubated in Fura-2AM for $30 \mathrm{~min}$ at $37^{\circ} \mathrm{C}$ in $5 \% \mathrm{CO}_{2}$. Excess and non-hydrolysed Fura-2AM was removed by washing the cells twice in PBS. Cells were finally resuspended at a concentration of $1 \times 10^{6}$ cells $/ \mathrm{ml}$ in Hanks' solution containing $1.25 \mathrm{mM} \mathrm{Ca}^{2+}$, at $37^{\circ} \mathrm{C}$. Two millilitres of cells were pipetted into a glass cuvette, maintained in suspension with a magnetic stirrer and placed in a Perkin-Elmer LS-50 fluorospectrophotometer (Foster City, CA, USA). Using excitation and emission wavelengths of 340 and $510 \mathrm{~nm}$ respectively, and slit widths of $5 \mathrm{~mm}$, fluorescence was measured under basal and CTstimulated conditions. Maximal and minimal fluorescence of each sample was established by addition of $0 \cdot 1 \%$ Triton $\mathrm{X}-100$ and then by simultaneous addition of $2 \mathrm{mM}$ EGTA and $25 \mathrm{mM}$ Tris- $\mathrm{HCl}$ respectively. The free intracellular calcium concentration was calculated according to Grynkiewicz et al. (1985), using the dissociation constant of $220 \mathrm{nM}$ for Fura-2AM.

\section{Measurement of extracellular $\mathrm{pH}$}

Cells transfected with the insert - ve hCTR, insert + ve hCTR or vector alone, were plated at $1.5 \times 10^{6}$ cells per well in six-well plates and incubated in complete DMEM, as described, which contained $40 \mathrm{mM}$ sodium bicarbonate and $20 \mathrm{mM}$ Hepes buffer. Forty-eight hours after plating, cells remained untreated or were treated with $10 \mathrm{nM}$ sCT and the extracellular $\mathrm{pH}$ in medium from triplicate wells was measured 12, 24, 36, 48 and $72 \mathrm{~h}$ after the commencement of treatment, using a $\mathrm{pH}$ electrode.

\section{Cell growth analysis}

To determine the effect of sCT on cell growth, cells were plated in $25 \mathrm{~cm}^{2}$ tissue culture flasks at $2 \times 10^{5}$ cells $/$ flask or in six-well plates at $1 \times 10^{5}$ cells/well. Forty-eight hours after plating, cells remained untreated or were treated in triplicate either with $10 \mathrm{nM}$ sCT, $50 \mu \mathrm{M}$ PD-98059 (Biomol Research Laboratories Inc., Plymouth Meeting, PA, USA) in 0.05\% DMSO as vehicle, DMSO alone, or a combination of these reagents, as indicated in the Figures. Cells were harvested by trypsinisation and counted manually using a haemocytometer. Data are expressed as mean cell number per well \pm s.E.M. Where indicated the results were analysed by one-way ANOVA, and the level of significance was determined from a Tukey's post hoc test.

\section{Cell cycle analysis}

Cells released by trypsinisation were collected by centrifugation, resuspended in ice-cold PBS and then fixed in absolute methanol for at least $30 \mathrm{~min}$. Cells were then washed in PBS containing $0.5 \%$ Tween 20, followed by two washes in PBS containing 2\% FCS and resuspended in PBS $/ 2 \%$ FCS containing $40 \mu \mathrm{g} / \mathrm{ml} \mathrm{RNase} \mathrm{A} \mathrm{and} \mathrm{incu-}$ bated for a further $20 \mathrm{~min}$ at $37^{\circ} \mathrm{C}$. Cells were washed in $\mathrm{PBS} / 2 \%$ FCS and were finally resuspended in PBS containing propidium iodide (Sigma) at a final concentration of $20 \mu \mathrm{g} / \mathrm{ml}$. The stained nuclei were analysed using a flow cytometer (Epics Profile; Coulter). Cell cycle distribution was based on $2 \mathrm{~N}$ and $4 \mathrm{~N}$ DNA content.

\section{RNA extraction and Northern blot analysis}

For Northern blot analysis, cells were seeded at a density of $1 \times 10^{5}$ cells $/ 25 \mathrm{~cm}^{2}$ flask, allowed to attach for $48 \mathrm{~h}$ and then incubated for various times in the absence or presence of $10 \mathrm{nM}$ sCT. Total RNA was isolated using the TRIZOL Reagent (Gibco BRL), according to the manufacturer's instructions. Total RNA (10 $\mu \mathrm{g}$ per lane) was electrophoresed in formaldehyde/1\% agarose gels, transferred to Hybond $\mathrm{N}^{+}$nylon membranes (Amersham Pharmacia Biotech), and immobilised by UV crosslinking. Membranes were prehybridised for $3 \mathrm{~h}$ at $42{ }^{\circ} \mathrm{C}$ in $1 \mathrm{M} \mathrm{NaCl}, 1 \% \mathrm{SDS}, 10 \%$ dextran sulphate, $50 \%$ formamide, $100 \mu \mathrm{g} / \mathrm{ml}$ heat-denatured herring sperm DNA and hybridised with human p21 WAF1/CIP1 CDNA (a kind gift from Dr Helena Richardson, The University of Adelaide, South Australia, Australia), radiolabelled with $\left[\alpha-{ }^{32} \mathrm{P}\right] \mathrm{dCTP}$ by random priming using the Giga prime kit (Bresatec, South Australia, Australia). To allow quantification of mRNA signals, the same filters were stripped and then reprobed with a $450 \mathrm{bp}{ }^{32} \mathrm{P}$-labelled PCR-generated DNA fragment of human glyceraldehyde-3-phosphate dehydrogenase (GAPDH). Signals were analysed using the PhosphorImager SF (Molecular Dynamics Inc., Sunnyvale, CA, USA).

\section{Western blotting}

Cells were lysed in lysis buffer containing $10 \mathrm{mM}$ Tris-HCl, pH 7·6, $150 \mathrm{mM} \mathrm{NaCl,} \mathrm{1 \%} \mathrm{Triton} \mathrm{X-100,}$ 
$0 \cdot 1 \%$ SDS and stored at $-70{ }^{\circ} \mathrm{C}$ until ready to use. Cell extracts containing equal amounts of protein were mixed with an equal volume of sample buffer containing $12 \mathrm{mM}$ Tris- $\mathrm{HCl} \mathrm{pH} 6 \cdot 8,6 \%$ SDS, 10\% $\beta$-mercaptoethanol, 20\% glycerol, $0 \cdot 03 \%$ and bromophenol blue. Protein samples were boiled for $5 \mathrm{~min}$ and electrophoresed under reducing conditions in 14-20\% polyacrylamide gels. Separated proteins were electrophoretically transferred to PVDF transfer membrane (Dupont NEN, Boston, MA, USA) and blocked in PBS containing 5\% blocking reagent (Amersham Pharmacia Biotech) for $1 \mathrm{~h}$ at room temperature. Immunodetection was performed overnight at $4{ }^{\circ} \mathrm{C}$ in PBS/blocking reagent containing $0 \cdot 1 \%$ Tween 20, using mouse monoclonal antibodies to phospho-ERK1/2 MAPK protein at a 1:1000 dilution (New England BioLabs, Beverly, MA, USA) or to the nonphosphorylated ERK1/2 MAPK protein at a 1:2000 dilution (Transduction Laboratories, Lexington, KY, USA). Filters were rinsed several times with PBS containing $0 \cdot 1 \%$ Tween 20 and incubated with a 1:2000 dilution of anti-mouse alkaline phosphatase-conjugate (Amersham Pharmacia Biotech) for $1 \mathrm{~h}$. Antibody labelled protein was detected using the Vistra ECF substrate reagent kit (Amersham Pharmacia Biotech) and quantified using a Fluorimager (Molecular Dynamics).

\section{Results}

\section{Binding specificity}

To compare ligand-receptor interactions in HEK-293 cells stably transfected with either insert + ve or insert - ve hCTR, binding competition curves were constructed using ${ }^{125} \mathrm{I}-\mathrm{sCT}$ as the radioligand with increasing concentrations of unlabelled sCT. The HEK-293 cell line expressing the insert - ve hCTR, previously described (Evdokiou et al. 1999), was compared with stably transfected clones expressing the insert + ve hCTR. The binding competition curves showed no consistent difference between the hCTR isoforms (data not shown). By Scatchard analysis, the insert - ve hCTR displayed a $K_{\mathrm{d}} \sim 2 \cdot 0 \pm 0 \cdot 4 \mathrm{nM}(n=3)$, with respect to $\mathrm{sCT}$. The cell line used in the experiments described below expressed a mean of $1 \cdot 43 \pm 0 \cdot 37 \times 10^{6}$ receptors per cell. The insert + ve hCTR had a similar affinity for $\mathrm{SCT}\left(K_{\mathrm{d}} \sim 3.3 \mathrm{nM}\right.$, $n=2)$, with the particular cell line chosen for the experiments described below expressing a mean of $2.29 \times 10^{6}$ receptors per cell.

\section{cAMP accumulation}

We have previously shown cAMP accumulation in BHK cells transfected with either the insert - ve or the insert + ve hCTR (Moore et al. 1995). However, the insert + ve hCTR cells responded with greatly reduced sensitivity to
CT. The results in HEK-293 cells were somewhat different. Treatment with sCT resulted in an accumulation of cAMP in cells expressing the insert - ve hCTR with significant accumulation at $0.01 \mathrm{nM}$ (Fig. 1A). In contrast, insert + ve hCTR transfected cells were essentially unresponsive to $\mathrm{CT}$, even at concentrations that were 1000-fold higher than were effective at the insert - ve hCTR (Fig. 1A).

\section{$\mathrm{Ca}^{2+}$ mobilisation}

Nanomolar concentrations of sCT were shown to induce a transient rise in intracellular calcium in BHK cells transfected with the insert - ve hCTR (Stroop et al. 1993), and we have reported similar activity of CT in HEK-293 cells stably transfected with the rat C1a CTR (Houssami et al. 1994). However, BHK cells expressing the insert + ve hCTR (Moore et al. 1995) were found to be unresponsive to $\mathrm{CT}$ with respect to $\mathrm{Ca}^{2+}$ mobilisation. It was therefore of interest to compare the ability of the hCTR isoforms to induce intracellular calcium in HEK-293 cells. Treatment of cells transfected with the insert - ve hCTR with sCT induced a rapid, doseresponsive increase in intracellular calcium similar to that shown in BHK cells (Fig. 1B). This increase in intracellular calcium was receptor isoform specific since maximally effective concentrations of CT for the insert - ve hCTR had no effect on intracellular calcium concentrations in cells transfected with the insert + ve hCTR (Fig. 1B). Likewise in HEK-293 cells transfected with the vector alone, CT had no effect on intracellular calcium concentration (data not shown).

\section{Changes in extracellular $p H$}

An interesting phenomenon was observed after CT treatment of HEK-293 cells transfected with either the insert - ve hCTR or the insert +ve hCTR. Despite the presence of media buffering agents, there was a timedependent increase in the acidity of the growth media in response to sCT treatment (Fig. 1C). This novel effect was of greater magnitude for cells transfected with the insert - ve hCTR. Treatment of cells transfected with the vector alone showed no change in extracellular $\mathrm{pH}$ after sCT treatment (Fig. 1C).

\section{Cell proliferation}

HEK-293 cells stably transfected with the insert - ve or insert + ve isoforms of the hCTR, were treated with sCT under conditions of optimal mitogenic stimulus $(10 \%$ FCS). Consistent with our previous report, a single addition of sCT to cells expressing the insert - ve hCTR profoundly inhibited cell proliferation, while parental HEK-293 cells or cells transfected with vector alone were not influenced by sCT (Fig. 2A). In contrast to cells 
expressing the insert - ve hCTR, CT did not alter the growth of cells expressing the insert $+v e$ hCTR isoform (Fig. 2B). In confirmation of this result, $\mathrm{sCT}$ also failed to alter the growth of a second, independent, HEK-293 cell line (Hi5) stably expressing the insert + ve hCTR (data not shown).

\section{Cell cycle analysis}

We have previously shown that CT treatment of cells expressing the insert - ve hCTR caused a persistent

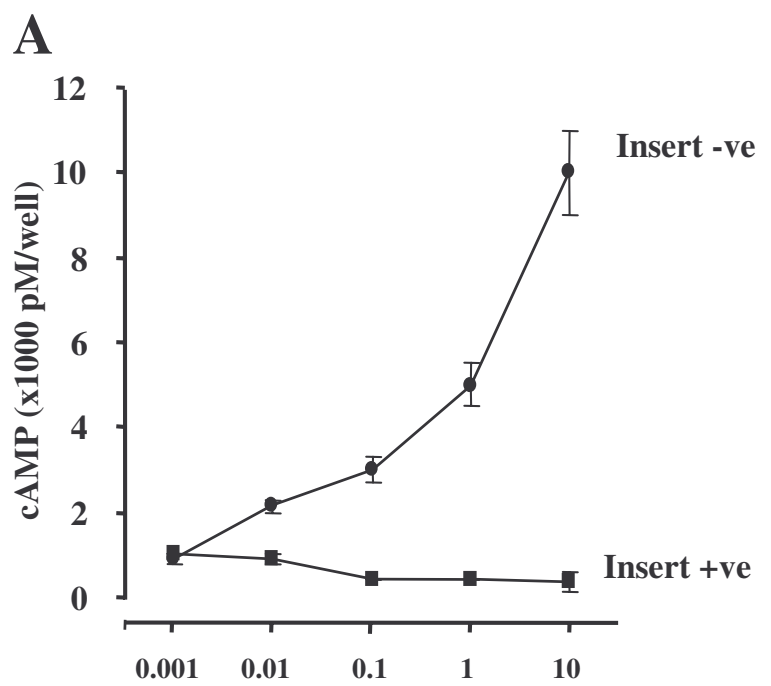

B
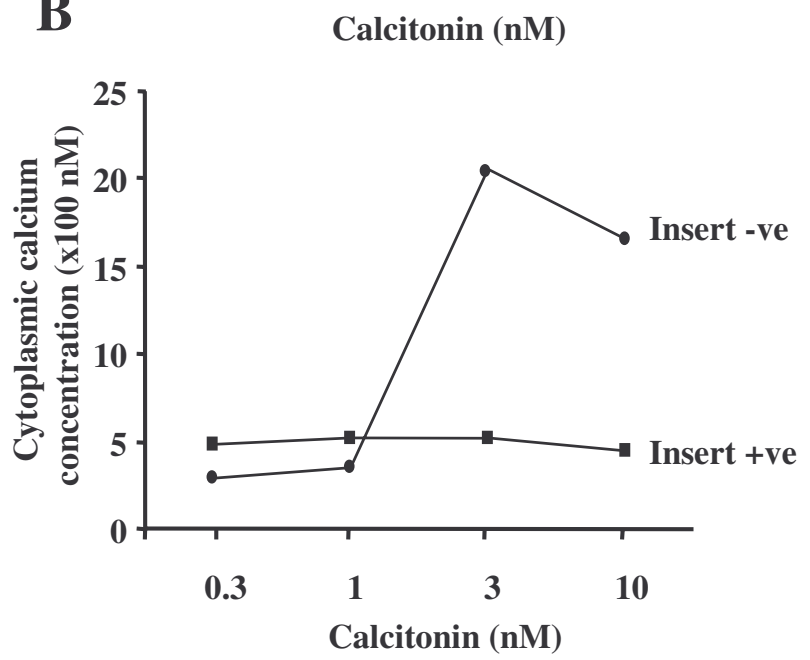

C

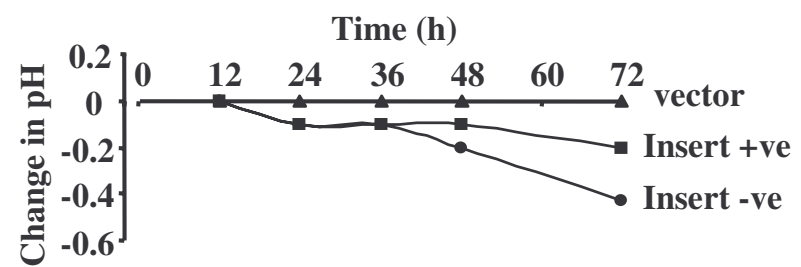

accumulation of cells in the G2 phase of the cell cycle with a parallel decrease in the number of cells in G1, compared with untreated cells (Evdokiou et al. 1999). In the present work we have compared the effect of CT on cell cycle parameters in cells expressing the insert + ve hCTR. We again found that treatment of cells expressing the insert - ve hCTR with $10 \mathrm{nM} \mathrm{sCT}$ for 24,48 or $72 \mathrm{~h}$, caused an accumulation of cells in G2 (Fig. 3A). The per cent increase in the number of cells accumulating in G2 following sCT treatment varied between $7 \cdot 5$ and $15 \cdot 2 \%$ in the three independent experiments performed. Consistent with the cell proliferation data, we found that $\mathrm{SCT}$ had no effect on cell cycle parameters in cells expressing the insert + ve hCTR, with up to $72 \mathrm{~h} \mathrm{CT}$ treatment (Fig. 3B). sCT did not influence cell cycle parameters in cells transfected with vector alone (data not shown).

\section{Sustained activation of Erk1/2 MAPK by CT}

To examine the effect of CT on activation of the ERK1/2 MAPK pathway, we determined the extent of phosphorylation of Erk1/2 in HEK-293 cells stably expressing either the insert - ve or insert + ve hCTR. Treatment with CT resulted in a minor and transient phosphorylation of Erk1/2 in the first hour of treatment. However, a marked induction of Erk1/2 phosphorylation was seen at the later time points that was sustained for more than $48 \mathrm{~h}$ in cells stably expressing the insert - ve hCTR (Fig. 4A, and later Fig. 8). Cells expressing the insert + ve hCTR or vector alone, showed no changes in the phosphorylation state of Erk1/2 in response to CT treatment (Fig. 4B and $\mathrm{C}$ ). Phosphorylation of Erk1/2 by CT was ligand dependent and was not seen in control cells incubated in the absence of CT (data not shown).

Inhibition of Erk1/2 MAPK pathway abrogates the growth inhibitory effects of CT

To investigate the involvement of the Erk1/2 MAPK pathway in regulation of cellular proliferation, the specific

Figure 1 (A) CT induction of intracellular CAMP accumulation. HEK-293 cells stably expressing the insert - ve $(\bullet)$ or the insert + ve hCTR $(\boldsymbol{\square})$ were treated with the indicated concentrations of sCT for $15 \mathrm{~min}$ at $37^{\circ} \mathrm{C}$. Cells were then lysed and assayed for intracellular cAMP content as described in Materials and Methods. The results are means \pm S.E.M. of triplicate determinations and are representative of two independent experiments. (B) Intracellular $\mathrm{Ca}^{2+}$ mobilisation. Suspensions of Fura-2AM-loaded HEK-293 cells expressing the insert - ve (-) or the insert + ve ( $)$ hCTR receptor were exposed to increasing concentrations of SCT. Cytoplasmic free $\mathrm{Ca}^{2+}$ was calculated as described in Materials and Methods. These data are representative of two independent experiments. (C) CT-induced extracellular acidification. HEK-293 cells stably expressing the insert - ve $(\bullet)$, the insert + ve hCTR $(\boldsymbol{\square})$ or vector alone $(\boldsymbol{\Delta})$ were treated $48 \mathrm{~h}$ after plating with $10 \mathrm{nM} \mathrm{sCT}$. At the indicated times the media $\mathrm{pH}$ of triplicate wells was measured. These results are means \pm S.E.M., with error bars obscured by the data points and are representative of three independent experiments. 


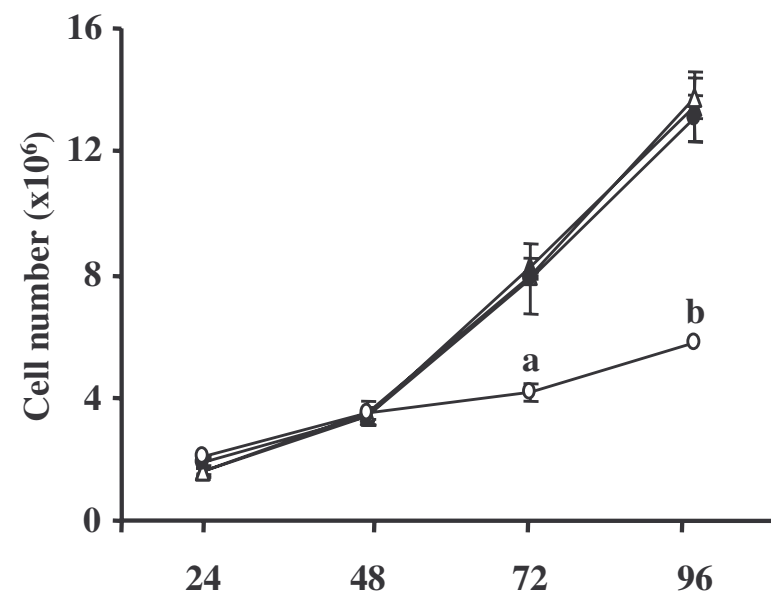

B

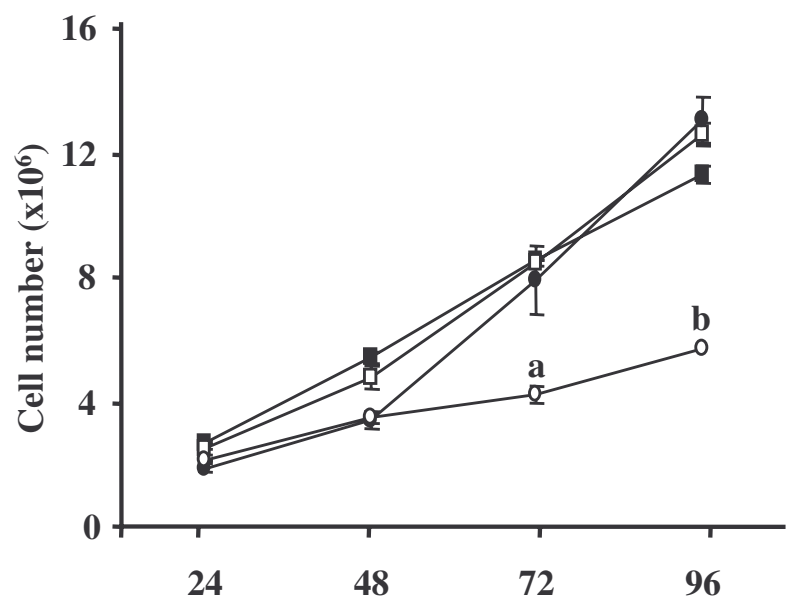

Time (h)

Figure 2 The effect of CT treatment on cell proliferation. HEK-293 cells transfected with the insert - ve $(\bullet, \bigcirc)$, insert + ve hCTR $(\boldsymbol{\square}, \square)$, or vector alone $(\boldsymbol{\Delta}, \triangle)$ were plated at $2 \times 10^{5}$ cells per T25 flask. Forty-eight hours following plating, cells remained untreated (closed symbols) or were treated once with $10 \mathrm{nM}$ sCT (open symbols). At the indicated times following commencement of treatment, cells were harvested and counted. (A) Shows vector alone vs insert - ve hCTR cells, (B) compares insert - ve and insert + ve hCTR cells. Data points are means \pm S.E.M. of triplicate determinations and are representative of three independent experiments; $a$ and $b$ denote significant differences from the respective control at each time $(P<0 \cdot 001)$.

MEK inhibitor PD-98059 was used. Proliferation of cells expressing the insert - ve hCTR was significantly decreased $(P<0 \cdot 001)$ following a $72 \mathrm{~h}$ exposure to $10 \mathrm{nM}$ sCT (Table 1). Cell growth was not altered when cells
A Insert -ve hCTR

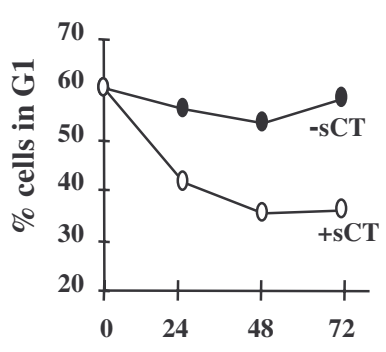

Time (h)

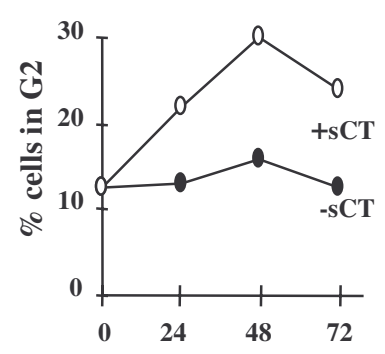

Time (h)

\section{B Insert +ve hCTR}

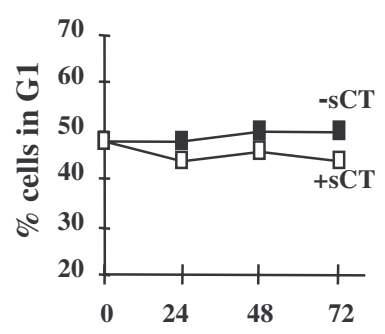

Time (h)

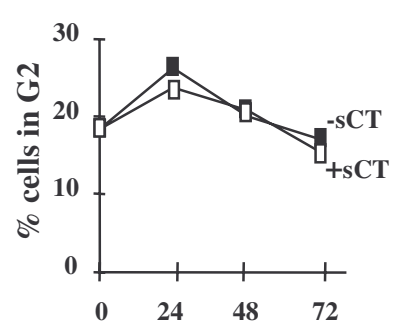

Time (h)
Figure 3 The effect of CT on cell cycle progression. HEK-293 cells transfected with the insert - ve $(\bullet, O)(A)$, or insert + ve hCTR $(\mathbf{\square}, \square)(B)$, were plated at $2 \times 10^{5}$ cells per $25 \mathrm{~cm}^{2}$ culture flask. Forty-eight hours after plating, cells were left untreated (closed symbols) or were treated once with $10 \mathrm{nM} \mathrm{sCT}$ (open symbol). Cells were harvested and fixed at the indicated times after treatment, stained and analysed for DNA content as described in Materials and Methods. Each data point represents the per cent of cells in the indicated phase of the cell cycle and the data are representative of three independent experiments.

were treated with vehicle or PD-98059 alone; however, simultaneous treatment with sCT and PD-98059 significantly $(P<0.001)$ abrogated the growth inhibitory effects of sCT (Table 1). None of these treatments altered the growth of cells expressing the insert + ve hCTR or those transfected with vector alone (Table 1).

To establish the involvement of ERK1/2 MAPK in the CT-induced accumulation of cells in the G2 phase of the cell cycle, cells expressing the insert - ve hCTR were collected $72 \mathrm{~h}$ after treatment and analysed by fluorescence-activated cell scanning. As shown in Fig. 3, treatment with sCT dramatically altered the cell cycle parameters, increasing the proportion of cells in the G2 phase. The PD-98059 alone did not alter the percentage of cells in G2 (Fig. 5). However, simultaneous treatment of cells with PD-98059 and sCT partially prevented the CT-induced accumulation of cells in G2 (Fig. 5). 

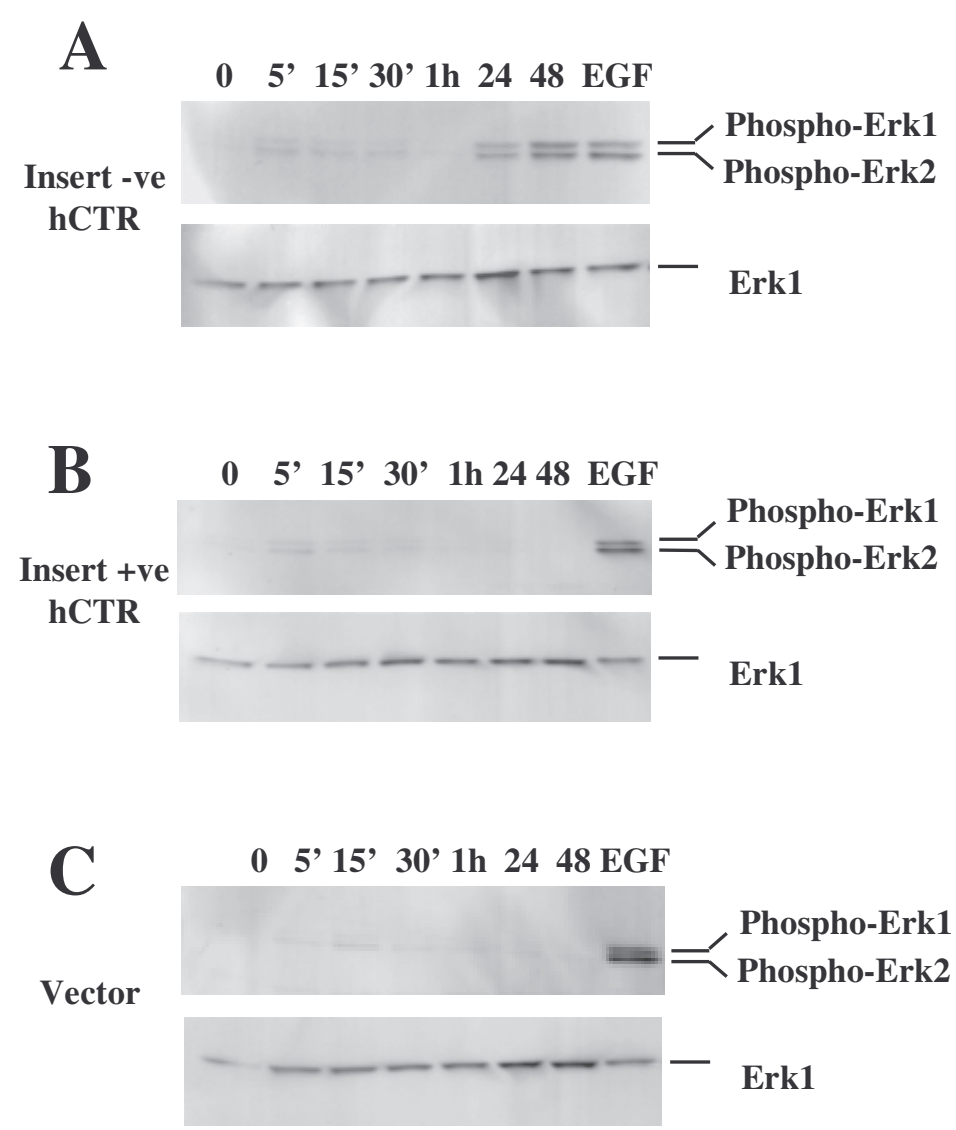

Figure $4 \mathrm{CT}$ activation of Erk $1 / 2$ is CTR isoform specific. Subconfluent HEK-293 cells stably expressing insert - ve hCTR (A), insert + ve hCTR (B) or vector alone $(\mathrm{C})$ were treated for the indicated times with $10 \mathrm{nM} \mathrm{sCT}$ or for $5 \mathrm{~min}$ with $10 \mathrm{ng} / \mathrm{ml}$ epidermal growth factor as a positive control. Cells were washed once in PBS and lysed in lysis buffer. Total cell extracts were processed as described in Materials and Methods for immunoblotting with anti-phospho-Erk1/2 to determine the phosphorylation state of Erk1/2 (upper panels) or anti-Erk1 antibody, to determine the total amount of protein in each sample (lower panels). These results are representative of three independent experiments.

Table 1 Effect of PD-98059 on CTR-mediated growth inhibition. HEK-293 cells transfected with the insert - ve, insert +ve hCTR or vector alone were plated at $1 \times 10^{5}$ cells/well in six-well plates. Forty-eight hours after plating, cells were treated with vehicle $(0 \cdot 05 \%$ DMSO), $10 \mathrm{nM} \mathrm{sCT}, 50 \mu \mathrm{M}$ PD-98059 or $50 \mu \mathrm{M}$ PD-98059 and $10 \mathrm{nM}$ sCT. Seventy-two hours after treatment cells were harvested and counted. Data points represent means \pm S.E.M. of triplicate determinations and are representative of three independent experiments

\begin{tabular}{|c|c|c|c|c|}
\hline & Cell numbe & $r$ well $(\times 10$ & & \\
\hline & Vehicle & sCT & PD-98059 & PD-90859+sCT \\
\hline Insert - ve hCTR & $578 \pm 3 \cdot 6$ & $155 \pm 4 \cdot 2^{\mathrm{a}}$ & $588 \pm 40 \cdot 6$ & $349 \pm 11 \cdot 2^{b}$ \\
\hline Insert +ve hCTR & $607 \pm 12 \cdot 4$ & $606 \pm 17 \cdot 0$ & $614 \pm 28 \cdot 4$ & $614 \pm 16 \cdot 5$ \\
\hline Vector & $600 \pm 36 \cdot 4$ & $617 \pm 36 \cdot 0$ & $597 \pm 31 \cdot 1$ & $589 \pm 23 \cdot 1$ \\
\hline
\end{tabular}

asignificant difference from control $(P<0 \cdot 001)$; ${ }^{b}$ significant difference from $\mathrm{sCT}$-treated $(P<0 \cdot 001)$. 

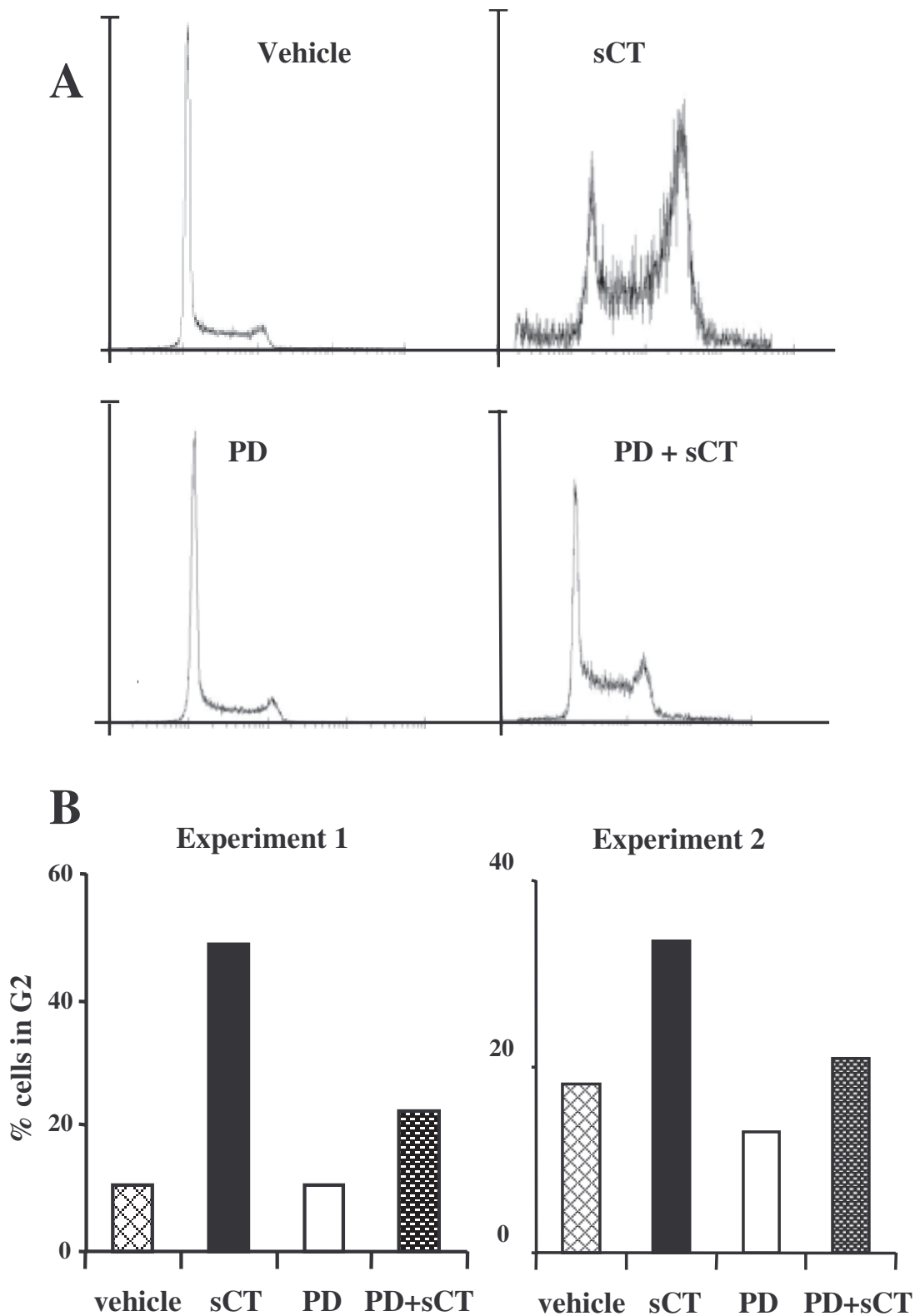

\section{Treatment}

Figure 5 Effect of PD-98059 on CT-induced changes in cell cycle progression. HEK-293 cells transfected with the insert - ve, insert + ve hCTR or vector alone, were plated at $1 \times 10^{5}$ cells/well in six-well plates. Forty-eight hours after plating, cells were treated with vehicle (0.05\% DMSO), $10 \mathrm{nM}$ sCT, $50 \mu \mathrm{M}$ PD-98059 or $50 \mu \mathrm{M}$ PD 98059 and $10 \mathrm{nM}$ sCT. Seventy-two hours after treatment cells were harvested and fixed, stained and analysed for DNA content, as described in Materials and Methods. (A) Distribution of cells in the cell cycle in response to the indicated treatment. (B) Summarises the per cent of cells in the G2 phase of the cell cycle in two separate experiments.

Effect of CT on expression of $p 21$ is dependent on isoform expression and Erk1/2 MAPK activation

We have previously shown that $\mathrm{SCT}$ increases the mRNA levels of $\mathrm{p} 21^{\mathrm{WAF} 1 / \mathrm{CIP} 1}$ in cells expressing the insert - ve
hCTR, as early as $4 \mathrm{~h}$ following sCT treatment and that the elevation of $\mathrm{p} 21^{\mathrm{WAF} 1 / \mathrm{CIP} 1}$ is causally related to the CTR-mediated growth inhibition of HEK-293 cells (Evdokiou et al. 1999). This effect of CT at the insert - ve 


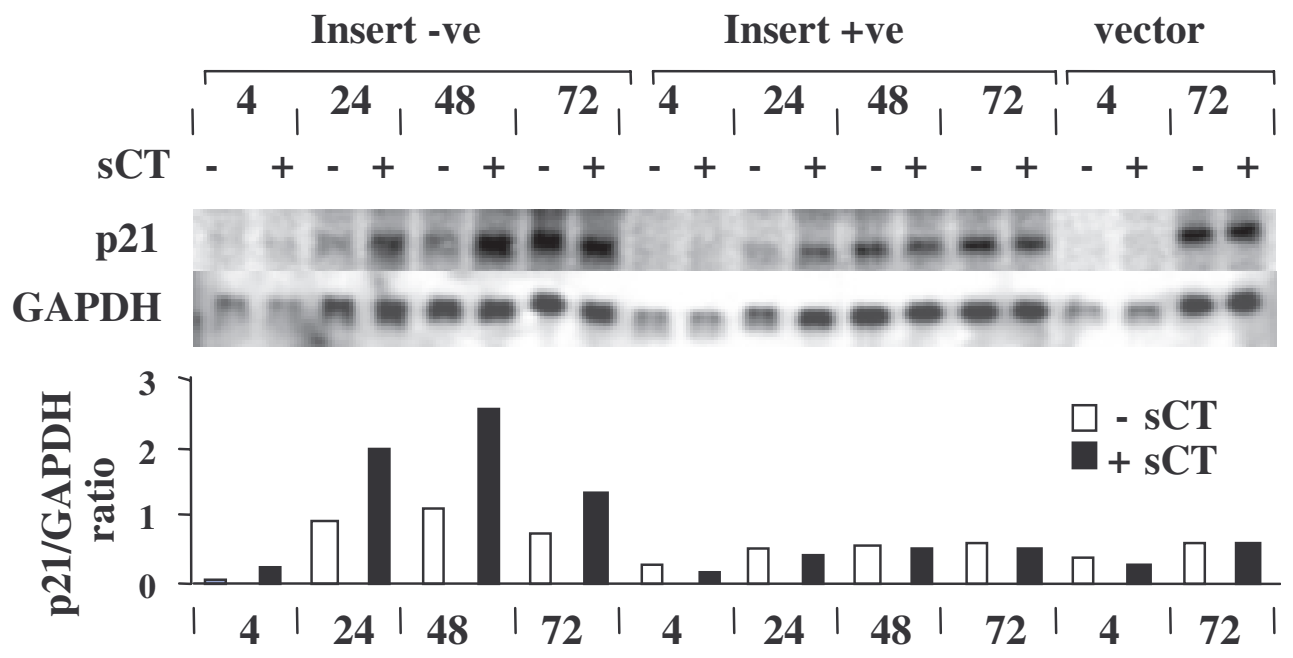

Figure 6 Expression of p21 mRNA after treatment with CT. HEK-293 cells stably transfected with the insert - ve, insert + ve hCTR, or vector alone were cultured for the indicated times in the absence or presence of $10 \mathrm{nM}$ sCT, added once $48 \mathrm{~h}$ after plating the cells. Total RNA was extracted and Northern blot analysis performed. RNA was electrophoresed in a 1\% agarose formaldehyde gel, transferred to nylon membrane and hybridised with a ${ }^{32}$ P-labelled p 21 cDNA probe. Blots were rehybridised with a cDNA probe for GAPDH to indicate RNA loading. Signals were analysed by densitometry and expressed in the lower panel as a ratio of p21 mRNA/GAPDH mRNA. These results are representative of two independent experiments.

hCTR is shown in Fig. 6, which also shows that sCT did not affect the steady state levels of $\mathrm{p} 21^{\mathrm{WAF} 1 / \mathrm{CIP} 1} \mathrm{mRNA}$ in cells expressing the insert +ve hCTR at any time point investigated. Similarly there was no change in p21 WAF1/CIP1 $m$ RNA in cells transfected with vector alone (Fig. 6).

To establish the involvement of ERK1/2 MAPK in the CT-induced elevation of p21 WAF1/CIP1 mRNA levels, cells expressing the insert - ve hCTR were treated with PD-98059. As shown in Fig. 7, sCT treatment of these cells again induced a prolonged increase in the steady state levels of $\mathrm{p} 21^{\mathrm{WAF} 1 / \mathrm{CIP} 1}$ mRNA. PD-98059 prevented the CT-induction of $\mathrm{p} 21^{\mathrm{WAF} 1 / \mathrm{CIP} 1} \mathrm{mRNA}$ at $24 \mathrm{~h}$, although the inhibition was partial at $48 \mathrm{~h}$ and was overcome by $72 \mathrm{~h}$.

To determine the ability of PD-98059 to inhibit Erk1/2 activity in culture, cell lysates were analysed for Erk1/2 phosphorylation. Figure 8 shows that PD-98059 completely inhibited the sCT-induced Erk1/2 phosphorylation at 24 and $48 \mathrm{~h}$ time points. However, at the later time point of $72 \mathrm{~h}$ PD-98059 inhibition of the sCT-induced phosphorylation of Erk1/2 was partial (Fig. 8). PD-98059 alone did not affect Erk1/2 phosphorylation compared with control cells (data not shown).

\section{Discussion}

CT is most often considered as a calciotrophic hormone and is best understood in terms of its action as a potent

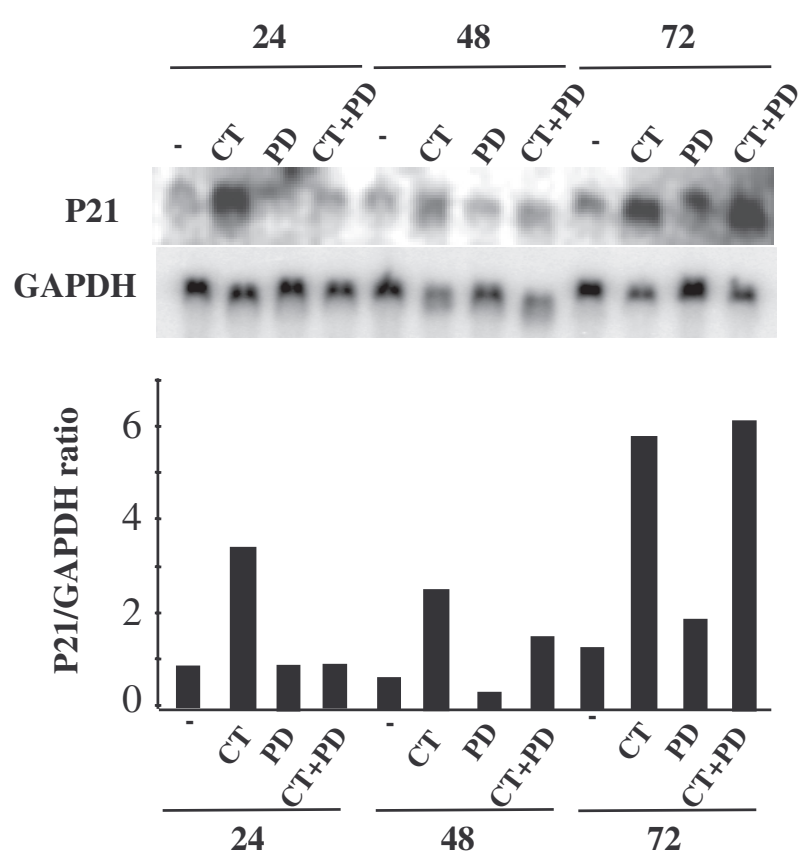

Figure 7 Effect of PD-98059 on p21 mRNA expression. HEK-293 cells stably transfected with the insert - ve hCTR were cultured for the indicated times with vehicle (0.05\% DMSO), $10 \mathrm{nM} \mathrm{sCT}$, $50 \mu \mathrm{M}$ PD-98059 or $50 \mu \mathrm{M}$ PD-98059 and $10 \mathrm{nM}$ sCT. Total RNA was extracted and Northern blot analysis performed. RNA was electrophoresed in a 1\% agarose formaldehyde gel, transferred to nylon membrane and hybridised with a ${ }^{32}$ P-labelled p21 cDNA probe. Blots were rehybridised with a cDNA probe for GAPDH to indicate RNA loading. Signals were analysed by densitometry and expressed in the lower panel as a ratio of p21 mRNA/GAPDH mRNA. These results are representative of two independent experiments. 
24

48

72

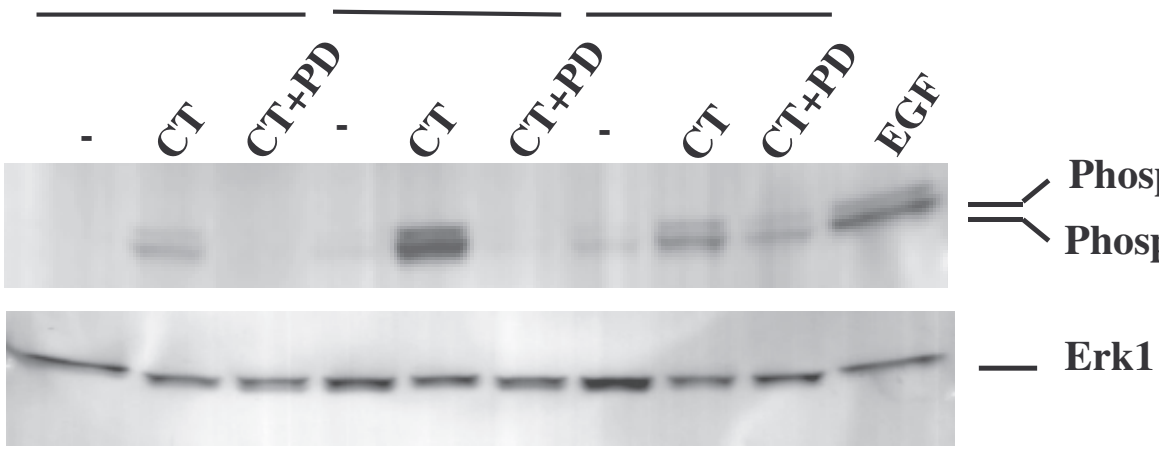

Figure 8 Effect of PD-98059 on Erk1/2 phosphorylation. HEK-293 cells stably transfected with the insert - ve hCTR were cultured for the indicated times with vehicle (0.05\% DMSO), $10 \mathrm{nM} \mathrm{sCT,} 50 \mu \mathrm{M}$ PD-98059 or $50 \mu \mathrm{M}$ PD-98059 and $10 \mathrm{nM}$ sCT. Total cell extracts were collected, electrophoresed on an SDS-PAGE gel and transferred to PVDF membrane as described in Materials and Methods. Immunoblotting with anti-phosphoErk1/2 was performed to determine the phosphorylation status of Erk1/2 (upper panel) and anti-Erk1 antibody to determine the total amount of protein in each sample (lower panel). These results are representative of two independent experiments.

inhibitor of osteoclastic bone resorption (Martin et al. 1998). However, it is likely that the CT/CTR system has actions unrelated to calcium homeostasis and skeletal preservation since both CT and CTR are expressed in extraskeletal sites (Fischer et al. 1981, Hilton et al. 1998, Nicholson et al. 1988). Examples of additional roles for CT are physiological inhibition of prolactin secretion in the anterior pituitary (Shah et al. 1996) and evidence that CT promotes implantation and early differentiation of blastocysts in the pregnant uterus (Zhu et al. 1998). In reconsidering the physiology of $\mathrm{CT}$, it is necessary to understand the significance of the CTR isoforms that result from alternative splicing of the primary transcript, and that are expressed in a tissue-specific manner (Kuestner et al. 1994). In particular, transcripts corresponding to the insert + ve isoform of the hCTR are expressed as a minor product in most tissues examined, relative to the insert - ve transcript and not at all in stomach and brain, but are well expressed in ovary and placenta (Kuestner et al. 1994). Interestingly, the insert + ve isoform appears to be always expressed together with the insert - ve isoform, although the converse is not true (Kuestner et al. 1994). This pattern of expression would make possible modulation of the insert - ve isoform by the insert + ve isoform, although there is no evidence for such an action as yet.

We have recently reported that CT treatment of HEK-293 cells stably expressing the hCTR insert - ve isoform potently inhibited cellular proliferation (Evdokiou et al. 1999). Here we have shown that the insert - ve hCTR isoform in HEK-293 cells mediates an increase in intracellular cAMP and cytoplasmic $\mathrm{Ca}^{2+}$ respectively, as found for the CTR in other cellular contexts (Moore et al. 1995). We have shown that HEK-293 cells expressing the insert - ve or the insert + ve hCTR isoform display similar binding characteristics for ${ }^{125} \mathrm{I}-\mathrm{sCT}$. This obser- vation agrees with the initial report of the binding kinetics of these receptor isoforms performed in BHK cells (Moore et al. 1995). In contrast, the insert + ve hCTR isoform did not activate Gs- or Gq-mediated signalling pathways in HEK-293 cells, even at concentrations of CT near maximal for activation by the insert - ve isoform. The ability of the insert +ve hCTR isoform to activate Gs thus appears to be cell-type dependent. For example, the $\mathrm{EC}_{50}$ for CT stimulation of adenylate cyclase was much greater for cells expressing the insert + ve compared with cells expressing the insert - ve hCTR in COS cells (Nussenzveig et al. 1994) and BHK cells (Moore et al. 1995). However, the maximal activation of adenylate cyclase was greatly reduced in COS cells (Nussenzveig et al. 1994) expressing the insert +ve hCTR but was not different between BHK cells (Moore et al. 1995) expressing the insert + ve or - ve hCTR. Significantly, CT treatment of HEK-293 cells transfected with either receptor isoform, lowered the media $\mathrm{pH}$. This suggests that the insert + ve hCTR is not simply a 'decoy' receptor, but has functional significance within the cells. The mechanism of this acidification activity is not understood; however, this finding suggests that the insert + ve hCTR may activate previously unrecognised signalling pathways. The action of CT to acidify the extracellular medium may be similar to the reported extracellular acidification by the PTH receptor in SaOS-2 cells (Barrett et al. 1997).

Surprisingly, CT treatment of HEK-293 cells transfected with the insert - ve hCTR caused a delayed and sustained activation of Erk1/2 in these cells. This delay is difficult to explain at present, but does correlate with morphological changes observed in the insert - ve cells after CT treatment. Cells accumulated in G2 at 24 and $48 \mathrm{~h}$ post-treatment displayed a rounded morphology and were loosely attached to the substratum. It is thus 
possible that Erk1/2 phosphorylation is a secondary effect of CT treatment following the primary morphological changes. Interestingly, CT was recently shown to alter focal adhesion kinase (FAK) and several FAK-associated proteins in HEK-293 cells (Zhang et al. 1999), suggestive of a role for CT in modulating cell attachment.

In the present experiments, activation of Erk1/2 was shown to be important for the CTR-mediated growth effects, since growth suppression by CT was partially blocked by the MEK inhibitor PD-98059. CT did not activate Erk1/2 in HEK-293 cells transfected with the insert +ve hCTR isoform. Moreover, the insert +ve hCTR isoform did not affect cellular proliferation in HEK-293 cells, consistent with an important role for the Erk1/2 pathway in the growth inhibitory action of CT in these cells. Recently, CT was reported to cause transient activation of Erk1/2 in HEK-293 cells transfected with the rabbit CTR (Chen et al. 1998), although the authors did not demonstrate a link between this activation and later events in the cells, in particular cell growth rate. It is important to note that those experiments were performed in low serum $(0.5 \%)$ conditions. The experiments described here were performed in optimal mitogenic conditions, in medium containing $10 \%$ FCS. In the latter conditions, we observed only a minor early and transient activation of Erk1/2, followed by a significant and prolonged activation. The CT-induced activation of Erk1/2 occurred in the same time frame as the induction of $\mathrm{p} 21^{\mathrm{WAF} 1 / \mathrm{CIP} 1}$ and inhibition of Erk1/2 phosphorylation inhibited $\mathrm{p} 21^{\mathrm{WAF} 1 / \mathrm{CIP} 1}$ expression. We have previously shown that the induction of $\mathrm{p} 21^{\mathrm{WAF} 1 / \mathrm{CIP} 1}$ is causally related to the inhibition of cell growth (Evdokiou et al. 1999). In this study we have provided evidence that Erk1/2 activation is in turn responsible for the CT-induced growth suppression and is upstream of $\mathrm{p} 21^{\mathrm{WAF} 1 / \mathrm{CIP} 1}$ induction, since inhibition of Erk1/2 abrogated both of these responses.

Although activation of Erk1/2 MAPK is usually associated with growth promotion (Mansour et al. 1994), a number of reports show that activation of Erk1/2 MAPK is also able to arrest cell cycling, and induce cellular differentiation (Cowley et al. 1994, Pumiglia \& Decker 1997). For example, nerve growth factor induces the activation of Erk1/2 MAPK and up-regulates expression of $\mathrm{p} 21^{\mathrm{WAF} 1 / \mathrm{CIP} 1}$ in NIH $3 \mathrm{~T} 3$ cells, resulting in the inhibition of cellular proliferation (Pumiglia \& Decker 1997). These effects were reversed by direct inhibition of MEK with PD-98059. When an inducible activated form of the Raf- 1 proto-oncogene was expressed in these cells it resulted in a prolonged increase in Erk1/2 MAPK activity and growth arrest, with a concomitant induction of p21 WAF1/CIP1 (Pumiglia \& Decker 1997). However, these events are clearly dependent on factors other than the type of cell, since transformation of NIH $3 \mathrm{~T} 3$ cells with a constitutively active MAPK kinase induced cellular transformation, allowing the cells to grow on soft agar and to form tumours in nude mice (Mansour et al. 1994). The ability of a signal transduction pathway to induce these conflicting cellular responses in the same cell type has been proposed to depend on the duration of Erk1/2 MAPK activation, with acute activation leading to growth stimulation and DNA synthesis, and chronic activation inhibiting cell cycle progression (Cowley et al. 1994, Tombes et al. 1998). In addition to the duration of the signal being important, there are reports that the intensity of the Erk1/2 MAPK signal may dictate the cellular response. For example NIH 3T3 cells, expressing an inducible Raf protein that could be progressively activated resulted in a G1 arrest and $\mathrm{p} 21^{\mathrm{WAF} 1 / \mathrm{CIP} 1}$ induction in response to a strong Raf signal. However, cellular proliferation was evoked in response to a moderate induction of $\mathrm{Raf}$ (Sewing et al. 1997, Woods et al. 1997). Thus it is becoming clear that the ultimate cellular response to activation of the Erk1/2 MAPK pathway is determined by the strength and duration of Erk1/2 MAPK signalling and also by the cellular context (Traverse et al. 1994).

In seeking a mechanism for the sustained activation of Erk1/2 MAPK observed in the present experiments, there are several possibilities. Chen et al. (1998) noted that CTR-induced activation of Erk1/2 in HEK-293 cells was partially inhibited by each of pertussis toxin, which inactivates $\mathrm{G} i$, and calphostin $\mathrm{C}$, a protein kinase inhibitor. In contrast, there was no evidence in those experiments for a role for protein kinase A (PKA) in Erk1/2 MAPK activation, although elevation of cAMP levels has long been associated with regulation of cell proliferation and differentiation (Cho Chung 1990). In addition, it was shown that inhibition by CT of T47D cell growth occurred in parallel with a selective and sustained activation of the type II isoform of PKA (Livesey et al. 1984) and CT strongly stimulated c-fos mRNA levels in both T47D and MCF7 cells, apparently by a cAMP-mediated mechanism (Lacroix \& Body 1997). There is a body of literature that suggests that the expression and/or activation of the PKA II isoform leads to inhibition of cell growth and differentiated function, while activation of PKA I is inversely related (Cho Chung 1990). More recently, Shyu et al. (1999) have shown that, in addition to activation of Gs, the rat C1a CTR activated Gi in HEK-293 cells, although an inhibitory effect of Gi on adenylate cyclase in these cells was masked by the concurrent activation of PKC by CT. Very recently there have been several reports of a novel mechanism by which Gi can activate the Erk1/2 MAPK pathway (Auer et al. 1998, Mochizuki et al. 1999, Shefler et al. 1999). In particular, Mochizuki et al. (1999) have shown that, in addition to the free $\beta \gamma$ subunits of activated G $\alpha i$ interacting with the Erk1/2 MAPK pathway via ras and raf, the free activated Gai subunit can independently activate this pathway by binding to and blocking the tonic Erk1/2 inhibitory action of a small GTPase called Rap1. It is possible that binding at the CTR activates both pathways 
in HEK-293 cells to control the duration and intensity of the signal through the Erk1/2 MAPK pathway.

This study thus provides a basis on which to further explore the mechanisms of CT-induced anti-proliferative actions in HEK-293 cells and, more generally, the effects of $\mathrm{CT}$ on cell growth and differentiation. The results draw attention to a previously unrecognised action of CT to induce a sustained activation of the Erk1/2 MAPK pathway. Since the Erk1/2 MAPK activation and growth suppression were receptor isoform specific, this work raises the question of whether the insert + ve and insert - ve isoforms of the hCTR might cross-modulate their activity, in a manner now becoming recognised for other receptors of the 7 TMD class (Jordan \& Devi 1999).

\section{Acknowledgements}

This work was supported by The Kathleen Cunningham Foundation for Breast Cancer Research, Australia, and grants from the Adelaide Bone and Joint Research Foundation and Bristol-Myers Squibb/Zimmer. L-J R was supported by the Australian Research Council Small Grants scheme. The authors were grateful for the assistance of Dr Henry Betts, Department of Rheumatology, Queen Elizabeth Hospital, Adelaide, South Australia with the intracellular calcium measurements.

\section{References}

Albrandt K, Brady EM, Moore CX, Mull E, Sierzega ME \& Beaumont K 1995 Molecular cloning and functional expression of a third isoform of the human calcitonin receptor and partial characterisation of the calcitonin receptor gene. Endocrinology 136 $5377-5384$.

Auer KL, Spector MS, Tombes RM, Seth P, Fisher PB, Gao B, Dent P \& Kunos G 1998 Alpha-adrenergic inhibition of proliferation in HepG2 cells stably transfected with the alpha1B-adrenergic receptor through a p42 MAPkinase/p21 Cip1/WAF1-dependent pathway. FEBS Letters 436 131-138.

Barrett MG, Belinsky GS \& Tashjian AH Jr 1997 A new action of parathyroid hormone. Receptor-mediated stimulation of extracellular acidification in human osteoblast-like SaOS-2 cells. Journal of Biological Chemistry 272 26346-26353.

Chambers TJ \& Magnus CJ 1982 Calcitonin alters behaviour of isolated osteoclasts. Journal of Pathology 136 27-39.

Chen Y, Shyu JF, Santhanagopal A, Inoue D, David JP, Dixon SJ, Horne WC \& Baron R 1998 The calcitonin receptor stimulates She tyrosine phosphorylation and Erk1/2 activation. Involvement of Gi, protein kinase C, and calcium. Journal of Biological Chemistry 273 19809-19816.

Cho Chung YS 1990 Role of cyclic AMP receptor proteins in growth, differentiation, and suppression of malignancy: new approaches to therapy. Cancer Research 50 7093-7100.

Cowley S, Paterson H, Kemp P \& Marshall CJ 1994 Activation of MAP kinase kinase is necessary and sufficient for PC12 differentiation and for transformation of NIH 3T3 cells. Cell 77 841-852.

Evdokiou A, Raggatt L-J, Atkins GJ \& Findlay DM 1999 Calcitonin receptor-mediated growth suppression of HEK-293 cells is accompanied by induction of $\mathrm{p} 21$ WAF1/CIP1 and G2/M arrest. Molecular Endocrinology 10 1738-1750.
Findlay DM, deLuise M, Michelangeli VP, Ellison M \& Martin TJ $1980 a$ Properties of a calcitonin receptor and adenylate cyclase in BEN cells, a human cancer cell line. Cancer Research 40 1311-1317.

Findlay DM, Michelangeli VP, Eisman JA, Frampton RJ, Moseley JM, MacIntyre I, Whitehead R \& Martin TJ 1980b Calcitonin and 1,25-dihydroxyvitamin D3 receptors in human breast cancer cell lines. Cancer Research 40 4764-4767.

Findlay DM, Michelangeli VP, Moseley JM \& Martin TJ 1981 Calcitonin binding and degradation by two cultured human breast cancer cell lines (MCF7 and T47D). Biochemical Journal 196 513-520.

Fischer JA, Tobler PH, Kaufmann M, Born W, Henke H, Cooper PE, Sagar SM \& Martin JB 1981 Calcitonin: regional distribution of the hormone and its binding sites in the human brain and pituitary. PNAS 78 7801-7805.

Gillespie MT, Thomas RJ, Pu ZY, Zhou H, Martin TJ \& Findlay DM 1997 Calcitonin receptors, bone sialoprotein and osteopontin are expressed in primary breast cancers. International Journal of Cancer 73 812-815.

Gorn AH, Lin HY, Yamin M, Auron PE, Flannery MR, Tapp DR, Manning CA, Lodish HF, Krane SM \& Goldring SR 1992 Cloning, characterization, and expression of a human calcitonin receptor from an ovarian carcinoma cell line. Journal of Clinical Investigation 90 1726-1735.

Gorn AH, Rudolph SM, Flannery MR, Morton CC, Weremowicz S, Wang TZ, Krane SM \& Goldring SR 1995 Expression of two human skeletal calcitonin receptor isoforms cloned from a giant cell tumour of bone. The first intracellular domain modulates ligand binding and signal transduction. Journal of Clinical Investigation 95 2680-2691.

Grynkiewicz G, Poenie M \& Tsien RY 1985 A new generation of $\mathrm{Ca}^{2+}$ indicators with greatly improved fluorescence properties. Journal of Biological Chemistry 260 3440-3450.

Gutkind JS 1998 Cell growth control by G protein-coupled receptors: from signal transduction to signal integration. Oncogene $\mathbf{1 7}$ 1331-1342.

Halliday DA, McNeil JD, Betts WH \& Scicchitano R 1993 The substance $\mathrm{P}$ fragment $\mathrm{SP}-(7-11)$ increases prostaglandin E2, intracellular $\mathrm{Ca}^{2+}$ and collagenase production in bovine articular chondrocytes. Biochemical Journal 292 57-62.

Hilton JM, Mitchelhill KI, Pozvek G, Dowton M, Quiza M \& Sexton PM 1998 Purification of calcitonin-like peptides from rat brain and pituitary. Endocrinology 139 982-992.

Houssami S, Findlay DM, Brady CL, Myers DE, Martin TJ \& Sexton PM 1994 Isoforms of the rat calcitonin receptor: consequences for ligand binding and signal transduction. Endocrinology 135 183-190.

Jagger C, Gallagher A, Chambers T \& Pondel M 1999 The porcine calcitonin receptor promoter directs expression of a linked reporter gene in a tissue and developmental specific manner in transgenic mice. Endocrinology 140 492-499.

Jordan BA \& Devi LA 1999 G-protein-coupled receptor heterodimerization modulates receptor function. Nature $399697-700$.

Kuestner RE, Elrod RD, Grant FJ, Hagen FS, Kuijper JL, Matthewes SL, O'Hara PJ, Sheppard PO, Stroop SD, Thompson DL, Whitmore TE, Findlay DM, Houssami S, Sexton PM \& Moore EE 1994 Cloning and characterization of an abundant subtype of the human calcitonin receptor. Molecular Pharmacology 46 246-255.

Lacroix M \& Body JJ 1997 Regulation of c-fos and c-jun expression by calcitonin in human breast cancer cells. Calcified Tissue International $60513-519$

Livesey SA, Collier G, Zajac JD, Kemp BE \& Martin TJ 1984 Characteristics of selective activation of cyclic AMP-dependent protein kinase isoenzymes by calcitonin and prostaglandin E2 in human breast cancer cells. Biochemistry Journal 224 361-370.

Mansour SJ, Matten WT, Hermann AS, Candia JM, Rong S, Fukasawa K, Vande Woude GF \& Ahn NG 1994 Transformation of mammalian cells by constitutively active MAP kinase kinase. Science 265 966-970. 
Martin TJ, Findlay DM, Moseley JM \& Sexton PM 1998 Calcitonin. In Metabolic Bone Disease and Clinically Related Disorders, pp 95-12. Eds LV Avioli \& SM Krane. San Diego: Academic Press.

Marx SJ, Woodward CJ \& Aurbach GD 1972 Calcitonin receptors of kidney and bone. Science 178 999-1001.

Mochizuki N, Ohba Y, Kiyokawa E, Kurata T, Murakami T, Ozaki T, Kitabatake A, Nagashima K \& Matsuda M 1999 Activation of the ERK/MAPK pathway by an isoform of rap1 GAP associated with $\mathrm{Ga}_{i}$. Nature 400 891-894.

Moore EE, Kuestner RE, Stroop SD, Grant FJ, Matthewes SL, Brady CL, Sexton PM \& Findlay DM 1995 Functionally different isoforms of the human calcitonin receptor result from alternative splicing of the gene transcript. Molecular Endocrinology 9 959-968.

Naro F, Perez M, Migliaccio S, Galson DL, Orcel P, Teti A \& Goldring SR 1998 Phospholipase D- and protein kinase C isoenzyme-dependent signal transduction pathways activated by the calcitonin receptor. Endocrinology 139 3241-3248.

Ng KW, Livesey SA, Larkins RG \& Martin TJ 1983 Calcitonin effects on growth and on selective activation of type II isoenzyme of cyclic adenosine $3^{\prime}: 5^{\prime}$-monophosphate- dependent protein kinase in T 47D human breast cancer cells. Cancer Research 43 794-800.

Nicholson GC, D'Santos CS, Evans T, Moseley JM, Kemp BE, Michelangeli VP \& Martin TJ 1988 Human placental calcitonin receptors. Biochemical Journal 250 877-882.

Nussenzveig DR, Thaw CN \& Gershengorn MC 1994 Inhibition of inositol phosphate second messenger formation by intracellular loop one of a human calcitonin receptor. Expression and mutational analysis of synthetic receptor genes. Journal of Biological Chemistry $26928123-28129$.

Pumiglia KM \& Decker SJ 1997 Cell cycle arrest mediated by the MEK/ mitogen-activated protein kinase pathway. PNAS 94 448-452.

Ritchie CK, Thomas KG, Andrews LR, Tindall DJ \& Fitzpatrick LA 1997 Effects of the calciotrophic peptides calcitonin and parathyroid hormone on prostate cancer growth and chemotaxis. Prostate $\mathbf{3 0}$ 183-187.

Sewing A, Wiseman B, Lloyd AC \& Land H 1997 High-intensity Raf signal causes cell cycle arrest mediated by $\mathrm{p} 21 \mathrm{Cip} 1$. Molecular and Cellular Biology 17 5588-5597.

Shah GV, Rayford W, Noble MJ, Austenfeld M, Weigel J, Vamos S \& Mebust WK 1994 Calcitonin stimulates growth of human prostate cancer cells through receptor-mediated increase in cyclic adenosine $3^{\prime}, 5^{\prime}$-monophosphates and cytoplasmic $\mathrm{Ca}^{2+}$ transients. Endocrinology 134 596-602.

Shah GV, Pedchenko V, Stanley S, Li Z \& Samson WK 1996 Calcitonin is a physiological inhibitor of prolactin secretion in ovariectomized female rats. Endocrinology 137 1814-1822.

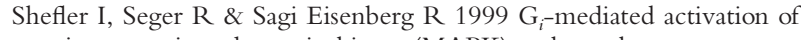
mitogen-activated protein kinase (MAPK) pathway by receptor mimetic basic secretagogues of connective tissue-type mast cells: bifurcation of arachidonic acid-induced release upstream of MAPK. Journal of Pharmacology and Experimental Therapeutics 289 1654-1661.

Shyu JF, Zhang Z, Hernandez Lagunas L, Camerino C, Chen Y, Inoue D, Baron R \& Horne WC 1999 Protein kinase C antagonizes pertussis-toxin-sensitive coupling of the calcitonin receptor to adenylyl cyclase. European Journal of Biochemistry 262 95-101.

Spengel R \& Eva C 1994 Hormone Receptors. In Handbook of Receptors and Channels, pp 153-157. Ed SJ Peroutka. Boca Raton: CRC Press.

Stroop SD, Thompson DL, Kuestner RE \& Moore EE 1993 A recombinant human calcitonin receptor functions as an extracellular calcium sensor. Journal of Biological Chemistry 268 19927-19930.

Tombes RM, Auer KL, Mikkelsen R, Valerie K, Wymann MP, Marshall CJ, McMahon M \& Dent P 1998 The mitogen-activated protein (MAP) kinase cascade can either stimulate or inhibit DNA synthesis in primary cultures of rat hepatocytes depending upon whether its activation is acute/phasic or chronic. Biochemistry Journal $3301451-1460$.

Traverse S, Seedorf K, Paterson H, Marshall CJ, Cohen P \& Ullrich A 1994 EGF triggers neuronal differentiation of PC12 cells that overexpress the EGF receptor. Current Opinion in Biology 4 694-701.

Wigler M, Silverstein S, Lee LS, Pellicer A, Cheng Y \& Axel R 1977 Transfer of purified herpes virus thymidine kinase gene to cultured mouse cells. Cell 11 223-232.

Woods D, Parry D, Cherwinski H, Bosch E, Lees E \& McMahon M 1997 Raf-induced proliferation or cell cycle arrest is determined by the level of Raf activity with arrest mediated by p21 Cip1. Molecular and Cellular Biology 17 5598-5611.

Zhang Z, Hernandez-Lagunas L, Horne WC \& Baron R 1999 Cytoskeleton-dependent tyrosine phosphorylation of the p103 cas family member HEF1 downstream of the G-protein-coupled calcitonin receptor. Journal of Biological Chemistry 274 25093-25098.

Zhu LJ, Bagchi MK \& Bagchi IC 1998 Attenuation of calcitonin gene expression in pregnant rat uterus leads to a block in embryonic implantation. Endocrinology 139 330-339.

Received 19 January 2000

Accepted 5 June 2000 